\title{
The Realignment of Subsidized Rice (Rastra) Policy into Non-Cash Food Assistance (BPNT) in Kalisat Sub-District of Jember District
}

\author{
Faiqoh Nurul Hikmah \\ SMKS Sunan Giri Pakusari Distric, Jember Regency \\ faiqohbilkis@gmail.com
}

\author{
Anastasia Murdiyastuti \\ University of Jember \\ anastasia.fisip@unej.acid
}

\begin{abstract}
Rastra is one of the social aids organized by Indonesian government to help the poor reduce their burden on the household. However, in 2017 the government amended this polic, called Non-cash food Assistance (BPNT). This new policy was operative based on 5 benchmarks of the alteration in attitudes and the behavior of the public and members of the bureaucracy, the alteration in leadership style, the efficiency of using sources, and the reduction of legalistic approaches. This research was commenced in November 2018 and aimed to analyze the transformation of Rastra Policy into BPNT, especially in Kalisat village, Jember district. The author revealed that this change had aimed to manage the stock of rice and the price because the government shared the aids once a month. The research data was taken from Kalisat village administration office which received the Rastra and each e-Warung organized by BPNT. The present study employed quantitative method. The author argued that, as the endeavour for poverty reduction, this policy needed improvement related to the target, the timing, the quality of the aids, and e-Warung readiness. The author contends that this realignment should be done based on the readiness of each infrastructur.
\end{abstract}

Keywords : Realignment, Implementation, Policy, Rastra, BPNT

\section{INTRODUCTION}

One of the social food assistance programs organized by the government is Raskin (Poor Rice) or Rastra (Prosperous Rice) and BPNT. The government of Kalisat village experienced various obstacles. This program actually aims to help the beneficiaries (KPM) in order to support their living. According to the Head of the Kalisat village, Mr. Sudi Raharjo, Kalisat is the most extensive area among 11 other villages with a comprehensive territory of $6.011 \mathrm{~km}^{2}$ and is found to be the most populated area in the region with 12.032 people (BPS Source, 2019 and Observation Results, November 2019).

The purpose of this study is to investigate the reform of rice distribution policy to the poor, wherein Rastra has turned into BPNT since 2017. The present study began in November 2018 by conducting Rastra research. To date, the program has turned into BPNT. This program was carried out because of the existence of community groups living below the poverty line especially those in the Kalisat village. 
The reform is expected to surmount the problems identified in the previous Rastra system. The government takes the initiative to hold existing rice stocks. This rice stock is initially managed through OPK (Specific Market Operations) to control high rice prices, which subsequently transforms into Raskin (Poor Rice) program. Later on it develops into the so called Rastra (Prosperous Rice). Usually the government distributes the rice once a month for the poor.

The subsidized rice program for the poor is part of the national food security system, which is implemented in a series of efforts to achieve food independence and sovereignty. Food is a human right that is protected by the 1945 Constitution. The primary food source in Indonesia is rice. Most of Indonesia's population consumes rice, so rice constitutes subtantially strategic national commodity.

Government policy has changed from Raskin to Rastra, and this has taken another form known as Non-Cash Food Assistance (BPNT). The quality of Raskin and Rastra rice is the same, commonly characterized by broken rice, poor small, low hygine due to fleas. To contrast, the rice in the BPNT program is much better with premium quality, guaranteed to have such poor qualities aforementioned.

The government's desire to provide better food assistance programs led to the establishment of the Ministry of Social Affairs Republic of Indonesia Regulation No. 25 of 2016 concerning Aid for the Development of Business Facilities through e-Warung (electronic stall) in article 1 paragraph 1 as follows:

"Direct initiative is compulsory upon assisting the poor. This attempt is integrated and sustainable under government management. Regional government and public hold the liberty to meet every individual's basic needs as stipulated by government's policy, program and pertinent facilities." (Surya Kharismawati, n.d.).

Based on the ministerial regulation above, any aid program takes the form of the NonCash Food Assistance (BPNT) to improve the previous program. BPNT is food social assistance in the form of non-cash from the government which is given to beneficiary families every month through an electronic account mechanism. The aid only means to support the purchase of food at food vendors or e-Warung in collaboration with banks.

It is appropriate that changes (bureaucratic reform) can excel management (public services) to be faster, simpler, easier, and more compliant with the public needs. This is a demand of the community because it is inseparable from progress and change in the community, especially in assessing the quality of every work carried out by the government. To meet the public needs, inevitably the government adapts to public ever-growing desires and demands. However, this reform has yet to instantly overcome the weaknesses in the aid distribution, nor has it achieved the initial goal of the program. This issue foregrounds the setting of the present study. It deals with the following research title The Realignment of Subsidized Rice (Rastra) Policy into Non-Cash Food Assistance (BPNT) in Kalisat Sub-District of Jember District.

Based on the description above, the formulation of the problem to be investigated is How was the realignment of subsidized rice (Rastra) policy into Non-Cash Food Assistance (BPNT) in Kalisat Sub-District of Jember District carried out? 


\section{RESULTS AND DISCUSSION}

The present study first commenced with field observation in November 2018, during which Rastra was still operative. Later, the program under investigation was turned into BPNT. This program was carried out because the community in the research site lived below the poverty line. The following data provide demographic information of the social, economic, and political background of the community.

Table 2.1 The Population in Each Hamlet in Kalisat Village or in 2017

\begin{tabular}{|c|c|c|c|c|c|c|c|}
\hline \multirow{2}{*}{ No } & \multirow{2}{*}{ Hamlet } & \multicolumn{3}{|c|}{ Number of People } & \multirow{2}{*}{$\begin{array}{c}\text { Number of } \\
\text { Families }\end{array}$} & \multirow{2}{*}{$\begin{array}{c}\text { Number of } \\
\text { Poor } \\
\text { Families }\end{array}$} & \multirow{2}{*}{$\begin{array}{l}\text { Percentage } \\
\text { of Poverty }\end{array}$} \\
\hline & & Male & Female & Total & & & \\
\hline 1. & Krajan 1 & 1396 & 1590 & 2986 & 788 & 506 & $64 \%$ \\
\hline 2. & Krajan 2 & 1507 & 1431 & 2938 & 650 & 415 & $63 \%$ \\
\hline 3. & Utara l & 631 & 908 & 1539 & 595 & 490 & $80 \%$ \\
\hline 4. & Utara 2 & 1346 & 1424 & 2770 & 530 & 487 & $85 \%$ \\
\hline 5. & Tengah & 683 & 765 & 1448 & 417 & 398 & $95 \%$ \\
\hline 6. & Barat & 997 & 1100 & 2097 & 511 & 409 & $80 \%$ \\
\hline & Total & 6560 & 7218 & 13778 & 3496 & 2705 & $77 \%$ \\
\hline
\end{tabular}

Source: Government of Kalisat Village

From the table above, the number of poor families is different in each hamlet. As for the hamlet, such as in Krajan 1 village, the number of poor families is 506 with the poverty rate of $64 \%$. Krajan 2 is found to have 415 poor families with poverty rate reaching 63\%. Utara 1 has 490 poor families, indicated by poverty rate of $80 \%$. Utara 2 has 487 poor families, with the poverty rate found at $85 \%$. Tengah region has 398 poor families with poverty rate raching 95\%. Barat region has 409 poor household with poverty rate of $80 \%$. The total number of poor families of all hamlets is 2.705 households with an overall poverty rate of $77 \%$. The data clearly indicates starking poverty rate of over $50 \%$ from the entire village.

Table 1.2 Population Growth in Kalisat Village

\begin{tabular}{|c|c|c|c|c|c|}
\hline \multirow{2}{*}{ Sex } & \multicolumn{4}{|c|}{ Year } & \multirow{2}{*}{$\begin{array}{c}\text { Average } \\
\text { growth } \\
(\%)\end{array}$} \\
\hline & 2014 & 2015 & 2016 & 2017 & \\
\hline Male & 6405 & 6488 & 6513 & 6.560 & 0,02 \\
\hline Female & 7015 & 7161 & 7180 & 7218 & 0,1 \\
\hline Total & 13.420 & 13.649 & 13.693 & 13.778 & 0,33 \\
\hline
\end{tabular}

From the table above, there were 6.405 men and 7.015 women in 2014, which constitutes a population of 13.420 people. In 2015 there were 6.488 men and 7.161 women, comprising a population of 13649 people. In 2016 there were 6.513 men and 7.180 women, with a total population of 13.693. In 20176.560 men and 7.218 were recorded, which resulted in a total population of 1.3778. From 2014 to 2017 the average growth of men was $0.02 \%$, while women were found to grow at rate of $0.1 \%$. The total 
growth rate involving men and women was $0.33 \%$. The research data has concluded that the birthrate of women is greater than men.

The data above revealed interesting facts associated with Rastra and BPNT in Kalisat village. The phenomena surrounding Rastra, that is similar quality of rice and distribution, unravels the following findings.

First, every RTS (targeted family) based on Bulog implementation is supposed to receive $15 \mathrm{~kg}$, but in fact they are only given $5 \mathrm{~kg}$ each. (Observation Results, October $24^{\text {th }} 2018$ ).

Second, the price of rice and added transportation per semester can be different from the previous price as it can either rise or fall. (Observation Results, October $25^{\text {th }}$ 2018).

Third, there has been the lack of willingness of officers to listen to complaints or suggestions from customers regarding shortcomings in the current distribution services. (Observation Results, September $20^{\text {th }} 2018$ )

Fourth, the program has yet to maintain its objective because usually RTS who have improved their prosperity are still considered eligible for receiving the assistance. Also, no aid is granted when beneficiaries pass away or move to another region. What seems to exarcebate the issue is that those living under poverty line may not receive support at all (Observation Results, November $2^{\text {nd }} 2018$ ).

Fifth, RTS feel disappointed because every 3 months the rice prices differ, both in rice price and in transportation costs. The usual price is Rp. 1600/kg including the delivery cost. Sometimes it changes between Rp. 1,000 and Rp. 2000, and sometimes Rp. 3.000 (Observation Results, November $5^{\text {th }}$ 2018)

Sixth, the officers have yet to be ready in providing services, as revealed by the the researchers. During the study, there were often only two officers, namely the village secretary and the head of the RT or RW. These agents were responsible to assist 2.074 poor families and 1.054 households, in collaboration with the head of each village (Observation Results, November $7^{\text {th }} 2018$ )

Seventh, huge number of village heads, such as that in Krajan II, has no awareness of their officers' slow response in distributing Rastra. This as a result has serious impact on customer disappointment. This was echoed by one of the RTS in Krajan II. He also reported that the rice was sometimes still left at the home of hamlet head (Observation Results, November $12^{\text {th }} 2018$ )

Eighth, the findings clearly reveal that the public are not treated as the way they should be. The researchers have found a lack of hospitality and integrity of the involved officers in serving the recipients of Rastra. This is the main reasy why many have voiced their disasspoinment toward the chief at several RWs in Krajan II. (Observation Results, November $12^{\text {th }} 2018$ )

Ninth, the availability of physical office facilities to store and distribute Rastra is not yet sufficient. At present, the service is only provided in front of the village office. The rice is piled in front of the village office yard. It is feared that rain will cause damage on the rice before it is received by the RTS (Observation Results, November $12^{\text {th }} 2018$ ) 
Tenth, there is no service equipment in distributing Rastra. For example, the only transportation employed to deliver the rice from the village office to the recipients' houses is pedicab or bentor (Observation Results, November $12^{\text {th }} 2018$ ).

Eleventh, the amount of rice received by each Rastra beneficiary is inaccurate. This results from the inaccurate amount of rice distributed to the village office. This amount does not meet the required amount of the total beneficiaries in the village. The study reports that, out of 2.705 beneficiaries, only 1.054 beneficiaries receive the rice. (Observation Results, November $12^{\text {th }} 2018$ )

Twelfth, distribution should be done on every $10^{\text {th }}$ day each month. However, in October and November 2018 this rice was not distributed, thus causing delays and questions among recipients. It was not until December $24^{\text {th }}$ that this new rice aid was distributed (Observation Results, November $12^{\text {th }}$ 2018).

In Glagahwero village of Kalisat district, there are irregularities including broken rice, transportation cost irregularities, and the absence of socialization concerning the distribution of Rastra every month. It is even almost impossible to predict the scheduled arrival of Rastra distribution. In addition, there is lack of special transportation for distributing Rastra (Observation Results, November 20 ${ }^{\text {th }}$ 2018).

It appears that the issue concerning the distribution of Rastra in Jember Bulog Office will never be resolved if the community does not participate in monitoring and evaluating the whole distribution. Basically, a number of community representative groups can be involved to oversee the distribution of Rastra, such as students, nongovernmental organizations (NGOs), youth organizations, village representatives, and board members from respective regions.

\section{CONCLUSION AND RECOMMENDATION}

\section{A. Conclusion}

The distribution of Raskin at the Kalisat Village Office can be seen from the relationship of government cooperation from high to low levels which has not been well coordinated. It is not fast enough to update data on Target Households, both those who have died, moved, and are not eligible for Raskin because they are able to meet their basic needs. There is no specific room for Raskin distribution serviceor any relevant access to information on subsidized rice services.

The distribution of BPNT in Kalisat Village has not been well coordinated. There has been no updated data on the number of beneficiaries, where it may change due to death, residential change, or economic status change. In addition, there is no special room for BPNT distribution services

\section{B. Recommendation}

1.Distribution officers are required to be more assertive in dealing with people who can sustain their lives economically. 
2. The cost to gain Rastra in each village is supposed to be different. This denotes a public complaint because every month the cost always changes throughout the year.

3. Coordinations across instutions have to be more organized because information on whether or not rice procurement comes is only coordinated by the village secretary and directly coordinated to the head of each hamlet as well as the local neighborhood, rather than under direct control of beneficiaries. The fundamental issue is the absence of room for complaints concerning Raskin distribution, such as customer services via telephone.

4. It is important that staffs be given training and guidelines on how to provide good service. It is unfair for the beneficiaries to receive $5 \mathrm{~kg}$ or $6 \mathrm{Kg}$ rice when they instead deserve $15 \mathrm{Kg}$. The entire assistance must be shared equally with all beneficiaries in the village.

5. Government needs to scaffold public awareness of the boundaries in distributing Rastra. There have been polemic and conflict in the society where people who can manage their daily needs still receive Rastra.

For the governments, the following concerns need to be addressed for better service and fairness.

1.The need for staff understanding of good service guidelines because in the field researchers ask that no service guidelines are known by the implementor. Although the service is considered fairly satisfactory.

2. Extending the data collection duration for a minimum of six months to one year. This is because those identified as KPMs are sometimes changed due to death, moving, and increased prosperity.

3. There need to be more focused attempts on increasing public awareness on who actually deserve receiving BPNT. The present study reveals that those who eventually become prosper can no longer receive BPNT. As a corollary, this causes polemic and conflict in the community. What is more, there need to be a clear poverty category from the social service or regents in tandem with health services from the city-level government. The only recommendations were only voiced by the policy implementers in the field, including the chiefs in each village, hamlet, and neighborhood.

\section{REFERENCES}

Books:

Bungin, Burhan. 2007. Metodologi Penelitian Sosial. Surabaya: Airlangga University Press.

Dun, William N. 2003. Analisis Kebijakan Publik. Yogyakarta: Gadjah mada University Press.

Ginanjar, Nugraha Jiwapraja. 1980. Analisis Kebijakan Publik. Jakarta: Acro.

Grindle, M.S. 1980. Politics and Policy Implementation in the Third World. Princeton, NJ: 
Princeton University Press.

Jann, Werner dan Kai Wegrich. 2015. Teori Siklus Kebijakan dalam Handbook Analisis Kebijakan Publik: Teori, Politik, dan Metode, editor Frank Fischer, Gerald J. Miller dan Mara S. Sidney. Terj. Imam Baihaqie (hlm 61-89). Bandung: Penerbit Nusa Media. Moleong. 2019. Metodologi Penelitian Kualitatif. Bandung: PT Remaja Rosdakarya Offset. Miles, Mathew B. dan A. Michael Huberman. 2014. Analisis Data Kualitatif. Jakarta: UI Press.

Rustanto, Bambang Dr. 2015. Menangani Kemiskinan. Bandung: Rosda Karya. Sugiyono. 2007. Memahami Penelitian Kualitatif. Bandung: Alfabeta.

Sugiyono. 2015. Metode Penelitian Kuantitatif, Kualitatif, dan RひD. Bandung: Alfabeta.

Sugiyono. 2013. Metode Penelitian Kualitatif. Bandung: Alfabeta.

Subarsono, AG. 2015. Analisis Kebijakan Publik. Yogyakarta: Pustaka Pelajar.

Zauhar, Soesilo. 1996. Reformasi Administrasi Konsep, Dimensi dan Strategi. Jakarta: Bumi Aksara.

\section{Journals:}

Akib, H. 2010. Implementasi Kebijakan: Apa, Mengapa, dan Mengapa. Jurnal Administrasi Publik, l(1), l-ll. $\quad$ Retrieved from http://ojs.unm.ac.id/index.php/iap/article/viewFile/289/6

Darfin, D. 2014. Kualitas Pelayanan Distribusi Beras Bersubsidi Perum Bulog Divisi Regional Sumatra Selatan Pada Kelurahan 35 Ilir Kecamatan Ilir Barat II Palembang. 12. Retrieved from https://ejournal.unsri.ac.id/index.php/jmbs/article/download/3173/1701

Bidang, K. K., Negeri, K. D., \& Sosial, K. 2018. Pedoman Khusus Pengelolaan Pengaduan Bantuan Sosial Pangan. 79.

Hendrayady, Agus. 2011. Reformasi Administrasi Publik. Jurnal Fisip UMRAH Vo.I, No.l.

Jenderal, D., Fakir, P., Sosial, K., \& Indonesia, R.2018. Implementasi Program Bantuan Sosial Non Tunai di Indonesia. 7(03), 146-161.

Kotambunan, L. 2016. Analisis Pengaruh Belanja Modal dan Indeks Pembangunan Manusia terhadap Kemiskinan di Sulawesi Utara.

Mentang dkk, F. A. 2017. Evaluasi Distribusi Program Pemerintah tentang Beras Miskin Kepada Masyarakat (Suatu Studi Desa Totolan Kecamatan Kakas Barat Kabupaten Minahasa). Jurnal Eksekutif, Vol 1, No, 12. Retrieved from https://ejournal.unsrat.ac.id/index.php/jurnaleksekutif/article/view/16043

Nisak, A. F. (n.d.). Implementasi Kebijakan Beras Miskin (Raskin) di Kecamatan Kenjeran Kota Surabaya: Studi Deskriptif pada Kelurahan Tanah Kalikendinding. 9. Retrieved from http://journal.unair.ac.id/download-fullpapers-jpm4lae228foofull.pdf

Saputra, N. 2013. Pendistribusian Beras Miskin (Raskin) di Kelurahan Delima Kecamatan Tampan Kota Pekanbaru Tahun 2016. Journal of Chemical Information and Modeling, 53(9), 1689-1699. https://doi.org/10.1017/CBO9781107415324.004

Mentang dkk, F. A. 2017. Evaluasi Distribusi Program Pemerintah tentang Beras Miskin 
Kepada Masyarakat (Suatu Studi Desa Totolan Kecamatan Kakas Barat Kabupaten Minahasa). Jurnal Eksekutif, Vol 1, No, 12. Retrieved from https://ejournal.unsrat.ac.id/index.php/jurnaleksekutif/article/view/16043

Rachman, B., Agustian, A., \& Wahyudi, N. 2018. Efektivitas dan Perspektif Pelaksanaan

Program Beras Sejahtera (Rastra) dan Bantuan Pangan Non-Tunai (BPNT). Analisis

Kebijakan Pertanian, 16(1), 1. https://doi.org/10.21082/akp.vl6nl.2018.1-18

Ramadhan, T. 2018. Efektivitas Program BPNT terhadap Peningkatan Kesejahteraan Masyarakat

Kecamatan Tampan Pekanbaru. 5, 1-14.

Sedarmayanti. 2019. Reformasi Administrasi Publik, Reformasi Birokrasi, dan

Kepemimpinan Masa Depan. Bandung: Refika Aditama.

Saputro, B. A., Noor, I., \& Siswidiyanto. 2015. Impelementasi Program Beras untuk

Masyarakat Miskin (Raskin) dalam Upaya Pengentasan Kemiskinan (Studi di Desa

Sidorharjo, Kecamatan Jambon Kabupaten Ponorogo. Jurnal Administrasi Publik, 3(12), 2028-2032.

Septian, M. D., Bahri, T. S., \& Makmur, T. 2013. Analisis Efektivitas Dan Efisiensi Distribusi

Beras Miskin (Raskin) Di Kecamatan Trienggadeng Kabupaten Pidie Jaya. 14(1), 70-78. https://doi.org/10.24815/agrisep.vl4il.910

Situmorang, C. H. 2016. Kebijakan Nasional Program Raskin. Retrieved from http://www.jurnalsocialsecurity.com/sosial/kebijakan-nasional-program-

Raskin.html.

Subarsono, A. 2015. Analisis Kebijakan Publik (VII). Yogyakarta: Pustaka Pelajar.

Surya Kharismawati, I. (n.d.). Implementasi Bantuan Pangan Non-Tunai (BPNT) melalui E-

Warung Di Kelurahan Sidosermo Kecamatan Wonocolo Kota Surabaya.

Suyanto, B. 2001. Kemiskinan dan Pemberdayaan Masyarakat Miskin.

Surya Kharismawati, I., \& Rosdiana, W. 2018. Implementasi Bantuan Pangan Non-

Tunai (Bpnt) Melalui E-Warung Di Kelurahan Sidosermo Kecamatan Wonocolo Kota Surabaya. Publika, 6(8).

\section{Statutory:}

Perekonomian, S. K. R. D. B. Instruksi Presiden Republik Indonesia Nomor 5 Tahun 2015 tentang Kebijakan Pengadaan Gabah/Beras dan Penyaluran Beras oleh Pemerintah. 2015.

Sekretaris Kementerian Koordinator Bidang Pembangunan Manusia dan Kebudayaan. Pedoman Umum Subsidi Pangan (Rastra). 2017.

Kemensos Optimistis Rastra Diganti Bantuan Pangan Non Tunai pada 2019 Halaman all - Kompas. (n.d.).

Maharani, P. (2017). Pedoman Umum Bantuan Pangan Non Tunai. 1-136.

Sekretaris Kementerian Koordinator Bidang Pembangunan Manusia dan Kebudayaan. Pedoman Umum Subsidi Pangan (Rastra). 2017.

The National Team For The Acceleration of Poverty Reduction. 2019. TNP2K | Welcome. Retrieved from http://www.tnp2k.go.id/ 
Winarni, A. T. 2012. Study Implementasi Program Raskin Di Desa Kebumen Kecamatan Sukorejo Kabupaten Kendal. Serat Acity-Jurnal Ilmiah, 1(2), 27-36.

Magazine:

Majalah Gempur Kemensos Salurkan Bantuan Pangan Non Tunai di Jember. (n.d.). 